\title{
Internet Censorship and Freedom of Expression in Nigeria
}

\author{
Vareba, Anthony Leva ${ }^{1}$, Nwinaene, Vivian-Peace ${ }^{1}$, Theophilus, Singto Barigborme ${ }^{1}$, \\ Ken Saro-Wiwa Polytechnic, Bori ${ }^{1}$ \\ ${ }^{1}$ Department of Mass Communication
}

\begin{abstract}
Internet regulation has become indispensable in today's globalized world; given the fact that online platforms have these last years, become serious tools for the perpetration of multiple forms of vices. Both democracies and autocratic countries have resorted to this paradigm to ensure a degree of sanity on their cyberspaces. This has often been to the dismay of many Net users, specifically the apologists of libertarianism and human right activists. Internet regulation has thus been problematic to many schools of thought; this because of the sometimes questionable approaches adopted by world governments to deal with cyber criminality in their countries. In tandem with this, it has often been argued that Internet censorship in most African countries has been more a threat to freedom on the Net in African countries, than a panacea to check online vices. Hinging on critical observations and secondary sources, this paper explores the extent to which this theory is true to the political situation in Nigeria. It provides the Nigerian perspective on internet censorship and specifically examines the ways in which government's draconian approaches to Internet regulation has affected digital rights and Internet freedoms in Nigeria.
\end{abstract}

Keywords: Internet Censorship, Internet Dangers, Freedom of Expression, Internet Freedoms, Human Rights.

\section{INTRODUCTION}

In spite of its monumental importance, the internet technology has, in recent times, become a veritable site of crime. The medium has increasingly been used by ill intentioned entities (notably terrorist groups, scammers and cyber stalkers among others), to commit a multiplicity of crimes. Terrorists and other fundamentalist groups in particular have been using the cyberspace to systematically radicalize youths and instigate extremely violent acts across the world; while inexperienced and misguided citizen journalists have been capitalizing on the loose nature of the medium to spread seditious messages, false information and rumors among others, thereby causing serious harm to influential individuals and important social institutions across the world. All these online vices have made the Internet to be regarded by most observers as a double-edged sword or a technology which is both a blessing and a curse. In view of all these Internet dangers, most governments have supported or embraced the idea of censoring the Internet, mostly for national/regional security reasons. In tandem with this, Internet censorship and other aspects of cyber law design have become a global phenomenon engulfing both the best democracies and the worst autocratic countries in the world. However, Internet censorship has remained not only an intensively publicized issue but the subject of a serious and seemingly eternal controversy. As noted by Qazi (1996), this serious controversy has precisely revolved around two questions: (i) is censorship really a necessary panacea to maintain a particular moral standard in world's societies? (ii) In the case that there should be a moral standard, what information should people have access to?

The above mentioned controversy has been made more pronounced by the draconian measures adopted these last years by both First and Third World countries in guise of Internet censorship. To many human right activists and libertarian quarters, Internet censorship (as observed in most countries) has simply turned out to be a serious threat to Internet freedom. As put by Babatunde and Tomiwa (2015), the various cyber laws adopted by most governments across the world have paradoxically made the civility of internet freedom to be under threat in most countries from the U.S.A. and U.K., to Malaysia and China among other climes. In guise of explanation, the two researchers review a number of egregious cases illustrating the fact that cyber laws in many countries across the world, endanger Internet freedom in one way or the other. They note that: 
According to Rule 41 of the Federal Rule on Criminal Procedure of the United States, a Magistrate Judge can issue warrants authorising government-sanctioned hacking anywhere in the country. Also, in the United States, Microsoft has challenged government on "secrecy" orders by the State to request access to user eMails. The Malaysian government recently asked bloggers to register their blogs before publishing any political commentary. (p.3)

This paper explores the Nigerian perspective on the issue of Internet censorship. It precisely seeks to examine the ways in which the Nigerian government's approaches to censoring the internet have constituted a threat to freedom of expression, particularly freedom on the net. The paper thus attempts to answer the following research questions: what is Internet Censorship? How it is implemented in Nigeria? How has is been a threat to freedom of expression? And what has been the Nigerian civil society's attitude towards government's approaches to internet censorship, particularly to the obnoxious effects of these approaches.

\section{DEFINING INTERNET CENSORSHIP}

Internet censorship could be defined as the control or suppression of online contents. These online contents include all what can be viewed, accessed and published on the Internet, going from simple email to internet blogs. Internet censorship therefore puts restriction on of information which can be publicized or viewed on online platforms. It may involve the blocking or filtering of copyrighted information deemed to be sensitive, pornographic or harmful to certain classes of individuals. Besides blocking and filtering, approaches to Internet censorship may include content removal, and (partial or total) Internet shut down.

Internet censorship is mainly implemented by government through some of its accredited agencies. It can equally be implemented by some specific private organizations either on behest of the government or on their own initiative. The paradigm varies from one country to another. While most western democracies (notably the U.S. and U.K.) have moderate Internet censorship mechanisms, undemocratic or partly democratic countries (notably China and the majority of Black African countries) go as far as limiting online access to vital information such as news; suppressing discussions among citizens and shutting down the Internet.

The Internet censorship paradigm emerged out of a specific range of imperatives, otherwise called pressures. These pressures or imperatives may be summed up as follows:

- The need to ensure national security

- The protection of minors against abusive online contents

- The need to protect human dignity through checking incidences of hate speeches, racial discriminatory messages on online platforms

- The protection of privacy

- The need to ensure information security (through the prevention of malicious harking)

- The protection of reputation (to combat issues such as libel, comparative and unlawful advertising) (European Union 1996).

- Protection of the intellectual property

\section{INTERNET CENSORSHIP IN NIGERIA}

Like other countries, Nigeria has adopted various tools to censor the cyberspace within its territory. While some of these tools have been describes as natural, others have virtually been extra judicial and quasi obnoxious in nature. The countries efforts towards Internet censorship can be seen in the bills adopted by the country to criminalize cybercrimes as well as in the various draconian and antidemocratic bills adopted circumstantially by the government to deal with cases of (perceived) abuses of the Internet by political adversaries. This section of the discourse will review some of these Internet censorship tools.

One of the first attempts by Nigeria to criminalize cyber offences occurred in 1995 with the draft legislation of the Electronic Crimes, Telecommunications and Postal Offences Decree. This legislation defined cybercrimes, providing sanctions to be meted on their perpetrators in the Nigerian 
territory. Other early cybercrime bills adopted by the Nigerian Federation include the Computer Security and Infrastructure Bill of 2005, the 2008 Electronic Provisions Bill, the 2011 Cyber Security Bill, the Electronic Transfer of Funds Crime Bill of 2011 and the Criminal Code Amendment for Offences Relating to computer Misuse and Cybercrimes of 2011 among others. Though these bills represented laudable governmental efforts towards regulating telecommunications and the use of internet-driven communications in Nigeria, most of them were quickly dropped due to lack of political will and government's inaptitude to "stay committed to the socio-legal growth" of the Nigerian citizenry (Tomiwa 2015).

Since 2015, Nigeria has witnessed another series of legislative projects aimed at regulating the cyber space and dealing with the ever increasing number of challenges on the Internet. Two examples of these projects have been the 2015 Cybercrime (Prohibition, Prevention etc) Act and the aborted Frivolous Petition Act of same year. The former is the main judicial tool used actually by the government to censor the Internet. Under this bill numerous a number of Nigerian internet users have been prosecuted for crimes such cyber stalking, manipulation of information, cyber laundering, harking, spamming and many other vices.

In guise of dealing with cases of cyber criminality, the Nigerian government has sometimes employed draconian approaches such as restriction to connectivity (internet shutdown), blocking and removal of online contents. In its fight against the Boko Haram insurgency, the government (Goodluck Jonathan's administration) instituted series of seasonal Internet shutdowns in the three Northeastern states of Borno, Adamawa and Yobe. These shutdowns were instituted from May to December 2013 and in March 2014 in a bid to hamper terrorists and insurgent groups' use of telecommunications to coordinate their military attacks in these regions. During the 2015, the National Communications Council (NCC) shut down an SMS short code used by the All Progressive Congress - the then opposition party - to fundraise. During the same electoral campaign seasons, online publishers such as Premium were victims of DDoS (Distributed Denial of Service) attacks presumably initiated by pro-government institutions (Freedom on the Net 2015). In addition to these, the Nigerian government has often taken muscled measures against bloggers and other citizen journalists' communications on the Net. Such muscles actions have most often targeted anti-government bloggers and citizen journalists. This will be explored in greater details in the subsequent section of this discourse.

\section{INTERNET CENSORSHIP AND ONLINE FREEDOMS IN NIGERIA}

Internet censorship is, in principle designed to tackle challenges on the Net and enable issues such as Internet security, data privacy and greater cyber-activities in countries. However, its implementation in most African countries has been characterized by many paradoxes. In effect, though the paradigm has, on one hand, appeared to be a panacea for a number of cyber crimes, it has on the other hand contributed to more issues, some of which include mismanagement of private information, abuse of digital rights and wanton disrespect of internet freedoms. It has generally been very difficult for African countries to find a balance between freedom of expression and the imperative to fight many serious online vices (such as cyber terrorism and extremism). No doubt, in many African countries, Internet censorship is most often equated with reduced or lack of Internet freedoms and government's unrepentant desire to politically intimidate the populace. In other words, Black African governments have, in their majority, been deploying Internet censorship as an instrument of political intimidation and violation of human rights. Very repressive legislations are adopted in the continent to prosecute and tactically neutralize political opposition on the Internet or social media. According to Freedom Houses' 2016 report titled Freedom on the Net, only two countries (South Africa and Kenya) have free cyberspaces. The rest of African countries are rated not free or partially free, in terms of Internet freedom. It goes without saying that this poor performance has mainly been due to the African countries' adoption of very stringent cyber laws and draconian approaches to dealing with (perceived) abuses of the Internet.

In tandem with this, Nigerian users of the Internet and social networks have these last years enjoyed only a partly free cyberspace. Though it is on record that cyber activities in the country has increased over years and that digital platforms have been appropriated by many human rights activists and citizen journalists to drive pro-democratic campaigns, it remains evident that using the Internet to criticize government or influential political quarters has continued to be a "risky" venture in the country. In effect, there have, in recent times, been several cases of abusive use of cyber laws against members of the opposition and citizen journalists who have dared criticized some government 
officials and influential quarters. During the 2015 general elections for instance the National Communications Council (NCC) shut down the SMS short code used the All Progressive Congress (an opposition party) conceived to fundraised for it political campaigns. According to many International observers, this act by a government agency could only be interpreted as a politically motivated ploy aimed at hampering freedom of expression.

Additionally, various cyber legislations have, in many instances, been used by some government agencies to virtually muzzle the press in the country. An egregious illustration of this sad reality is the fact that the Cybercrime (Prohibition, Prevention etc) Act has since its promulgation in 2015, been used to seriously crack down on many citizen journalists and online publishers. The Nigerian authorities have particularly exploited Section 24 of the legislation - which offers a series of provisions on cyber stalking - to nail many citizen journalists and try to subtly intimidate many antigovernment voices. This Section 24 stipulates that:

Any person who knowingly or intentionally sends a message or other matter by means of computer systems or network that -

... (b) he knows to be false, for the purpose of causing annoyance, inconvenience, danger, obstruction, insult, injury, criminal intimidation, enmity, hatred, ill will or needless anxiety to another or causes such a message to be sent: commits an offence under this Act and shall be liable on conviction to a fine of not more than N7,000,000.00 or imprisonment for a term of not more than 3 years or to both such fine and imprisonment.

(2) Any person who knowingly or intentionally transmits or causes the transmission of any communication through a computer system or network - ... (c) containing any threat to harm the property or reputation of the addressee or of another or the reputation of a deceased person or any threat to accuse... commits an offence under this Act and shall be liable on conviction - ... (ii) in the case of paragraph (c) ... of this subsection, to imprisonment for a term of 5 years and/or a minimum fine of N15, 000,000.00".

As it can be observed, the above mentioned provisions are clearly contrary to Section 39 of the Nigerian 1999 Constitution which plainly supports freedom of expression. This section of the Constitutional stipulates in its section one that "every person shall be entitled to freedom of expression, including freedom to hold opinions and to receive and impart ideas and information without interference". In spite of its anti-democratic nature, Section 24 of Cybercrime (Prohibition, Prevention etc) Act has been used to prosecute various anti-government users of the social media. On August $20^{\text {th }}, 2015$ for instance, a popular Nigerian blogger named Azare Musa Babale was arrested following his use of the social media (Facebook and Twitter) to criticize the policies of Bauchi governor Muhammad Abdullah Abubakar. Similarly, armed operatives of the Economic and Financial Crimes Commission arrested another blogger by name Abubakar Sadiq Usman on allegation of cyber stalking on August 8 of the same year. This arrest followed the blogger's regular posting of contents which was described as "offensive publications" by the EFCC. The Commission therefore arguably arrested Sadiq for "offences bordering on cyber stalking".

Nigerian policy makers' ardent desire to hamper freedom of expression can equally be seen in some of the anachronistic bills proposed by some Nigerian legislators in recent times. A case in point is the Frivolous Petitions Bill which was sponsored by Nigerian Senator Bala Ibn Na'Allah in the Nigerian Senate. Grosso modo, Section 1 to 3 of the Bill stipulates the following:

(i) It is unlawful for any person to submit a petition or statement intended to report the conduct of any person for the purpose of an investigation, inquiry and or inquest without a duly sworn affidavit in the High Court of a State or the Federal High Court confirming the content to be true and correct in accordance with the Oaths Act.

(ii) Any such petition and or complaint not accompanied by the aforesaid affidavit is rendered incompetent and shall not be used by any government institution, agency or bodies established by law in force in Nigeria. 
(iii) It is an offence to use, publish or cause to be published any petition or complaint not supported by a duly sworn affidavit and upon conviction, the culprit is liable to imprisonment for six months without an option of fine.

(iv) It is equally an offence for a person to act, use or cause to be used any petition or complaint not accompanied by a duly sworn affidavit, and on conviction such a person is liable to imprisonment for a term of two years or a fine of 2,000,000.00, or both.

A simple reading of these provisions reveals the Frivolous Petition (Prohibition etc) Bill as a serious menace to the civility of freedom of expression and opinion which is clearly guaranteed by the Nigerian Constitution and the African Charter on Human Rights and People's Rights. No doubt, the Bill was rejected due mainly to political pressure from the Nigerian populace. Some of government's draconian actions taken in guise of Internet censorship have often triggered various campaigns by human right activists. Human right initiatives such as Paradigm Initiative, Enough is Enough and Media Right Agenda have for instance initiated movements and coalitions aimed to challenge the constitutionality of some sections of the Cybercrimes Act. In a joint action, the three groups have sent a Digital Right and Freedom Bill to the parliament with an urgent call for a revision of the cyber laws. Similar actions by other civil society organizations are so common in the country. However, the positive dividends of such actions are still awaited.

\section{Conclusion}

It is now an accepted premise that Internet censorship is a necessity. It is a panacea to numerous online vices and other related challenges. It is for instance a good instrument to prevent or check incidences of online terrorism, cyber extremism, scamming and "Internet anarchy" among others. However, Internet censorship in most African countries including Nigeria has been characterized by a number of paradoxes. It has become an instrument of political intimidation by many of them. In Nigeria particularly, this paradigm has sometimes been used to crack down on anti-government bloggers and other citizen journalists. Precisely, the Nigerian government has adopted anachronistic and draconic measures to deal with bloggers and other Internet users who have criticized them on online platforms or have initiated digitally driven campaigns against the some government officials. Some Nigerian policy makers have even gone to the extent of sponsoring (proposed) legislations such the Frivolous Petitions Bill that are so obnoxious as some of the legislations that prevailed during the days of military dictatorship.

In view of all these indexes, it could be concluded that Internet censorship in Nigeria continue to constitute a threat to freedom of expression in general and internet freedoms in particular. The antidemocratic nature of some of the provisions of the country's cybercrime laws and the muscled actions taken in recent times against bloggers in the country evidence Nigerian political class' slow embrace of democracy. It is therefore not surprising that most international observatories continue to poorly rate the country in terms of press and internet freedom. This calls for greater human right and political activism aimed at pressuring Nigerian policy makers to amend the legislations used to regulate cyber activities in the country.

\section{REFERENCES}

[1] Aborisade, P.O., Howard, C., Beasley, D. \& Livingood, R. (2011). Citizen journalism: How technology transforms journalism business through citizen-reporters in Nigeria. International Journal of Strategic Information and Applications, 2(2), 1-11.

[2] Barlett, J. \& Miller, C. (2011). Truth, lies and the internet. A report into youth digital fluency. London: Demos.

[3] Endong, F.P.C. (2017a). "Watchdogging" versus adversarial journalism by state-owned media: The Nigerian and Cameroonian experience. IJELS: International Journal of English, Literature and Social Sciences, 2(2), p.8-17.

[4] Endong, F.P.C. (2017b). From dictatorship to African democracy: How has freedom of expression been improved in Nigeria and Cameroon? Journal of Media Studies, 31(1), 1-17.

[5] Enibehe, E. (2016). EFCC, cyber stalking and the threat to freedom of expression in Nigeria. Sahara Reporters. Retrieve June 12, 2017, from http://saharareporters.com/2016/08/09/efcccyber-stalking-and-threat-freedom-expression-nigeria-inibehe-effiong 
[6] European Union (1996). Illegal and harmful content on the Internet: Communication to the European Parliament, the Council, the Economic and Social Committee and the Committee of the Regions. Retrieved September 2017, from http://www2.echo.lu/legal/en/internet/content/ communic.htm.

[7] Freedom House (2015). Freedom on the net 2015. Nigeria. London: Freedom House.

[8] Freedom on the Net (2016). Silencing the Messenger: Communication apps under threat. London: Freedom House.

[9] Gillmor, D. (2014). We the Media: Grassroots Journalism by the People, For the People. London: O’ Reilly Media.

[10] Media Foundation for West Africa (2015). Nigerian Senate was withdrawn "Frivolous Petition Bill”. IFEX 25, (pp. 1-9), Lagos: Media Foundation for West Africa.

[11] NIRA (2015). Internet Censorship. Retrieved June 21, 2017, from https://www.nira.org.ng/niramedia/news-update/111-internet-censorship

[12] Nworgu, K. O. \& Amadi, Mike (2011). The mass media. In O.K. Nworgu (ed) Mass media and society in a globalizing and digital age, (pp.37-56), Owerri: Ultimate Books.

[13] O’Sullivan, T., Hartley, J., Saunders, D. \& Fiske, J. (1996). Key concepts in communication. New York: The Chaucer Press.

[14] Qazi, U. (1996). Internet censorship controversy. Retrieved June 15, 2017, 2017, from http://courses.cs.vt.edu/professionalism/Censorship/notes.html

[15] Snoddon, B. (2016). Back to the bad old days: Freedom of expression 'under seige' in Nigeria. Pen Organization. Retrieved May 10, 2017, from https://pen.org/back-to-the- bad-old-daysfreedom-of-expression-under-siege-in-nigeria/

[16] The Federal Republic of Nigeria (2015). Cybercrimes Acts. Abuja: Government Printers

[17] Tomiwa, I. (2016). The Nigerian Cybercrimes Act 2015: Is it uhuru yet? Retrieved June 21, 2017, from http://www.orderpaper.ng/nigerian-cybercrimes-act-2015-uhuru-yet/ 